\title{
Amazônia de mistérios e descobertas, Parintins a grande surpresa
}

\author{
Amazon of mysteries and \\ discoveries - Parintins, \\ the big surprise
}

\begin{abstract}
A bro os olhos, o coração e os sentidos, diante de tanta criatividade, gente bonita, simpática e acolhedora. Em Parintins todo mundo está sempre em forma: não há ônibus, as distâncias planas são percorridas a pé, de bicicleta ou de moto.

Fiz três viagens ao Amazonas para participar do festival, chegando antes para conhecer o lugar, acompanhar os preparativos, em clima de aquecimento para as três noites de apresentação do boi-bumbá. Nos quartéis-generais, grandes galpões, armam-se as alegorias e são feitas as fantasias. Na viagem de barco, de Manaus a Parintins, aprendo alguns passos, escuto as toadas e as primeiras das muitas estórias.

$\mathrm{Na}$ ilha de Tupinambarana, apaixono-me pelo que encontro. Tomo partido não de um nem de outro boi, mas do Boi, figura mítica, o último guardião da floresta. Viajo na cor, no movimento, no ritmo, na música. Interpreto o que vejo, procuro tornar mais azul o Caprichoso, mais vermelho o Garantido, mais dramática e esplendorosa a grande festa.

Desfruto a oportunidade ímpar de fotografar o ato da criação artística, o sonho projetado, encenado, vívido e emocionante. Nas tribos, na galera, as pessoas dançam de corpo e alma, tocam o sublime, exaltam os sentidos. Descobrem suas origens, dão vida nova a antigos rituais. Pesquisam as lendas, põem em cena cobrasgrandes, onças, mapinguaris, araras gigantes, anhangás, seres reais e fantásticos.

Extasio-me com os fogos de artifício, surpreendo-me com deus Tupã surgindo por trás da arquibancada, o pajé na contraluz, as
\end{abstract}


luzes de mercúrio do bumbódromo apagadas, a galera toda com rosas vermelhas acesas nas mãos. Uso a grande angular, opero em altíssima sensibilidade, jamais o flash, para não quebrar a mágica.

De repente, deparo-me a sós com o boi no meio da arena, posso retratá-lo em toda a sua majestade, contorno de luz na corcova, resplandecendo no escuro.

Vejo a cobra-grande de olhos flamejantes como faróis poderosos, a lua cheia logo acima, junto-as no mesmo fotograma, imagem futurista. O enorme pássaro azul levando no dorso a rainha do folclore, voando no céu amazônico, provoca-me um arrepio, a fotografia parece-me presente dos céus. Surpresa atrás de surpresa, o espetáculo é mágico, fruto da criatividade arrojada e sem limites do povo de Parintins.

Quero agradecer a quem primeiro me falou dessa festa extraordinária, Maria Laura Viveiros de Castro Cavalcanti, parceira na exposição recém-realizada na Organização das Nações Unidas (ONU), Amazon Ritual; à Funarte e ao Museu do Folclore Edison Carneiro, instituições que apoiaram o projeto em diversas fases.

A todos os artistas do boi, a toda a gente de Parintins, obrigada.

Loris Machado

Fotógrafa, cientista social 


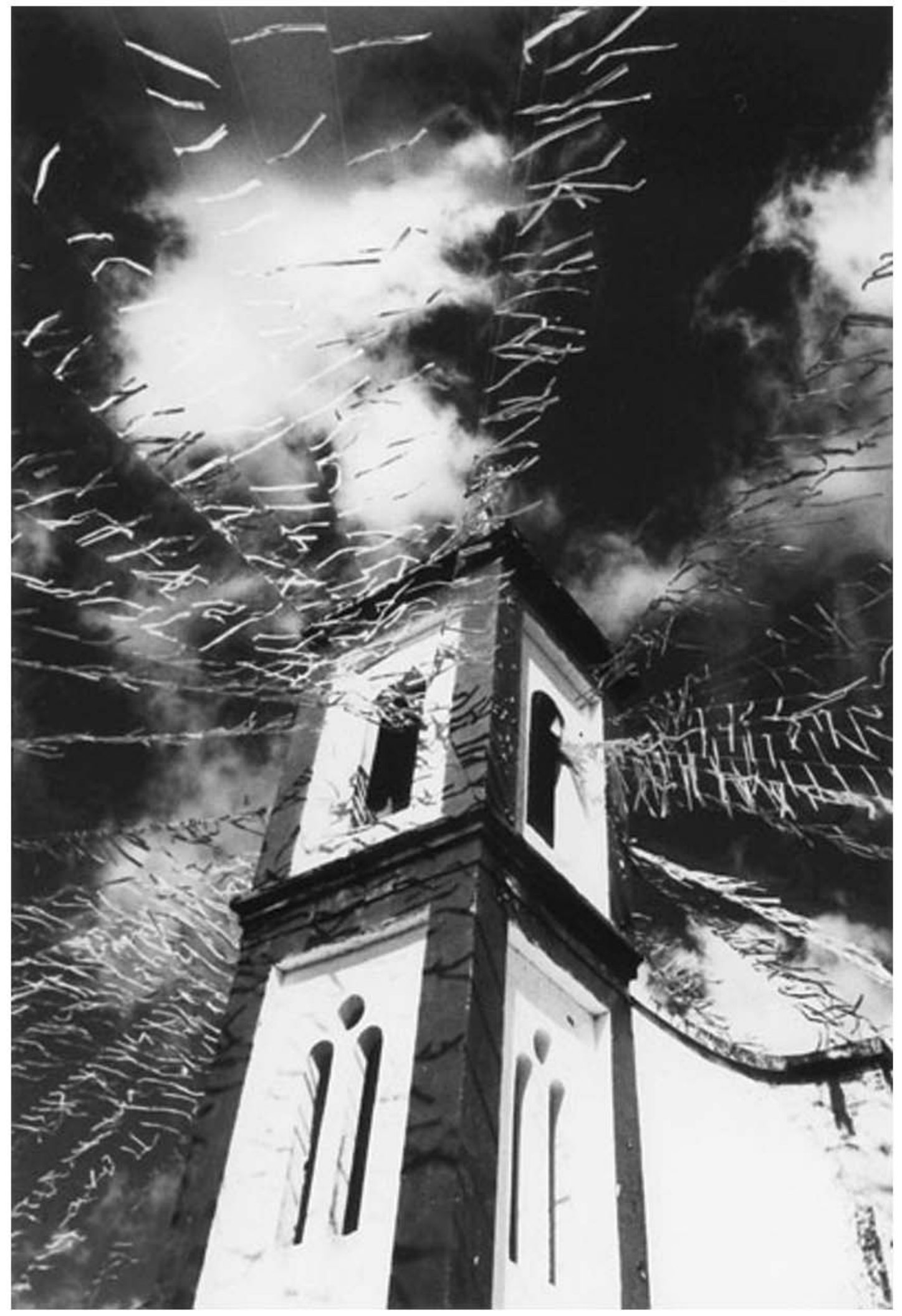

Igreja de São Benedito enfeitada para a festa 


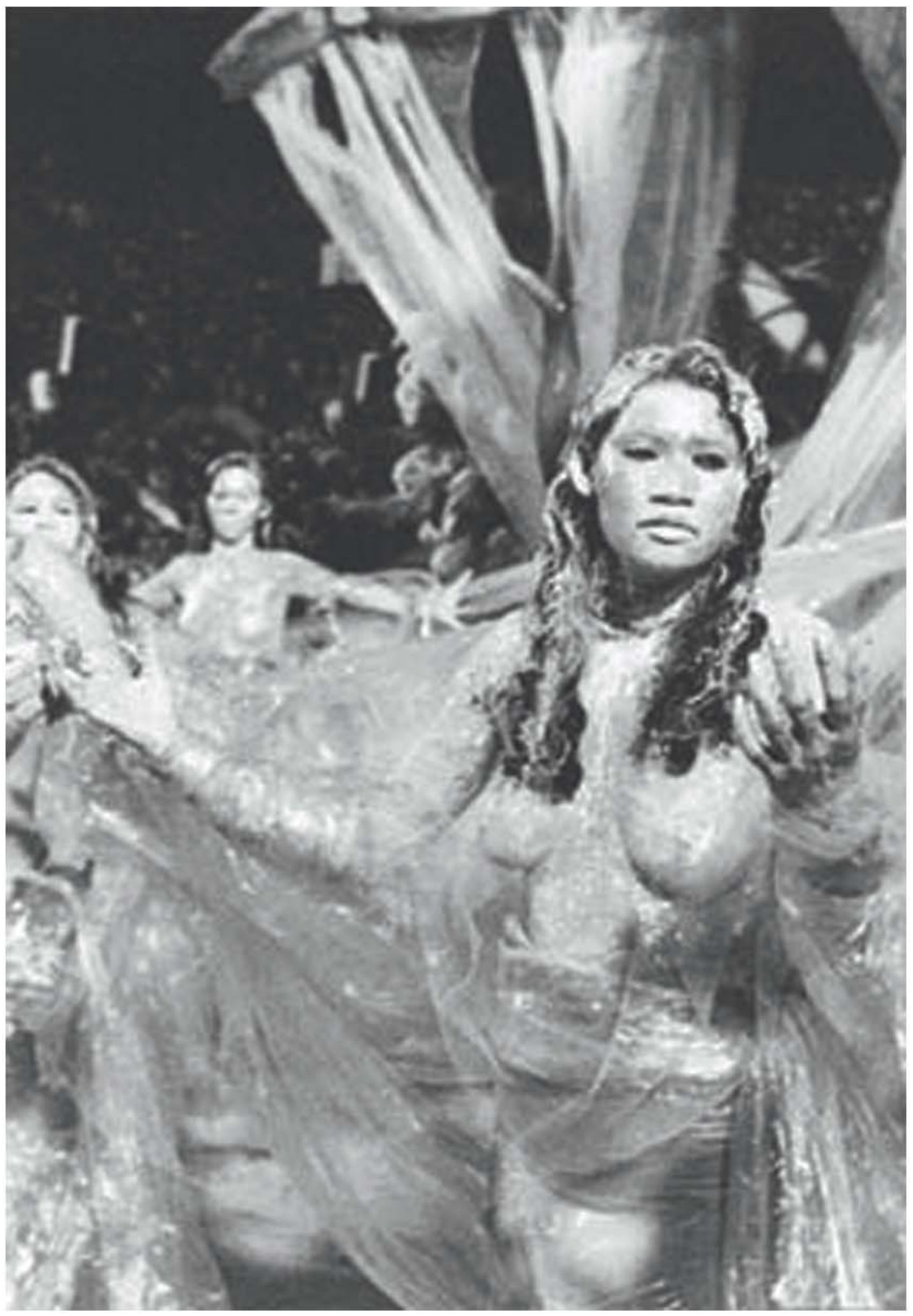

Lenda Amazônica, do Caprichoso 


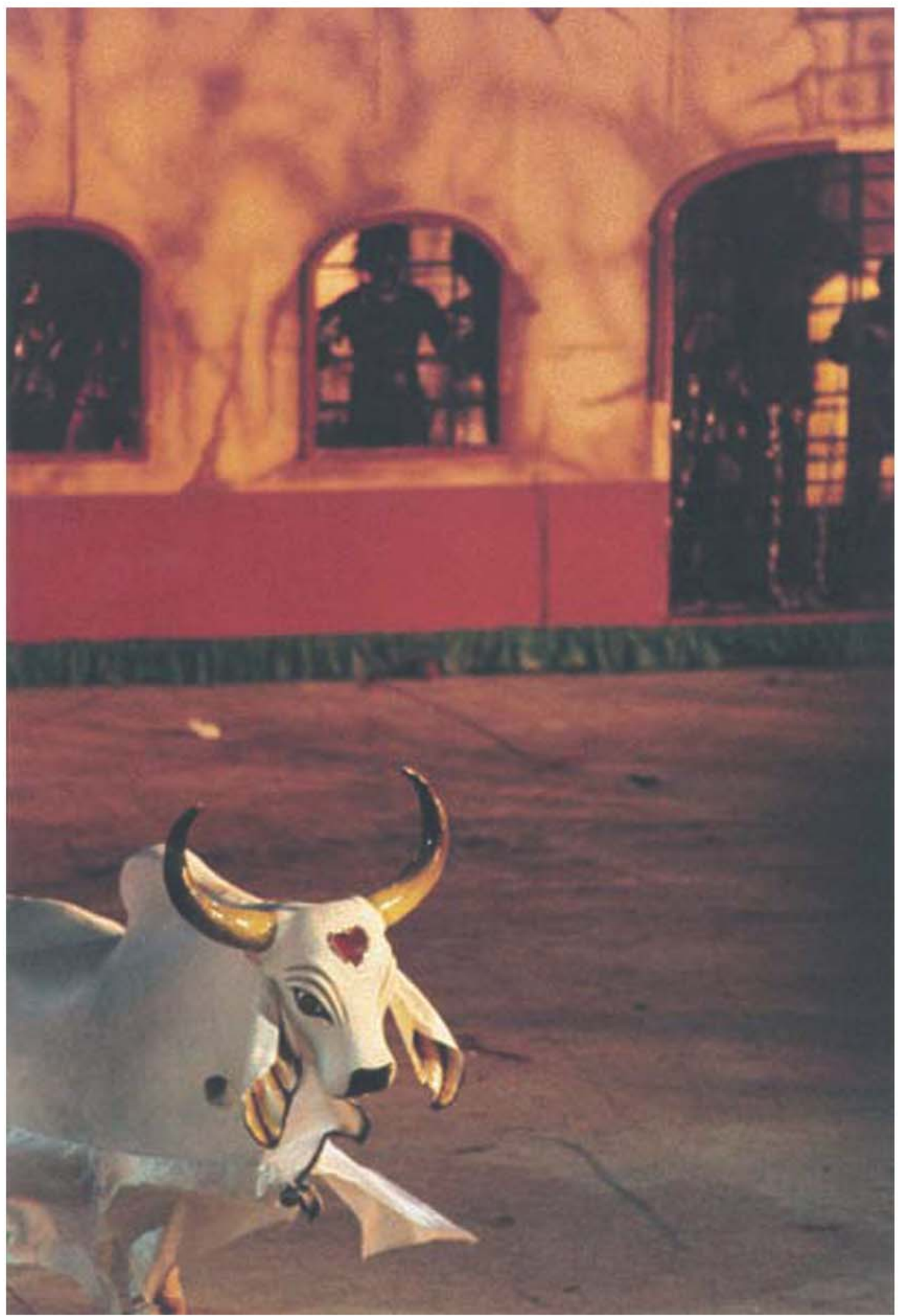

Boi do Garantido durante preparativos para as três noites do festival. 


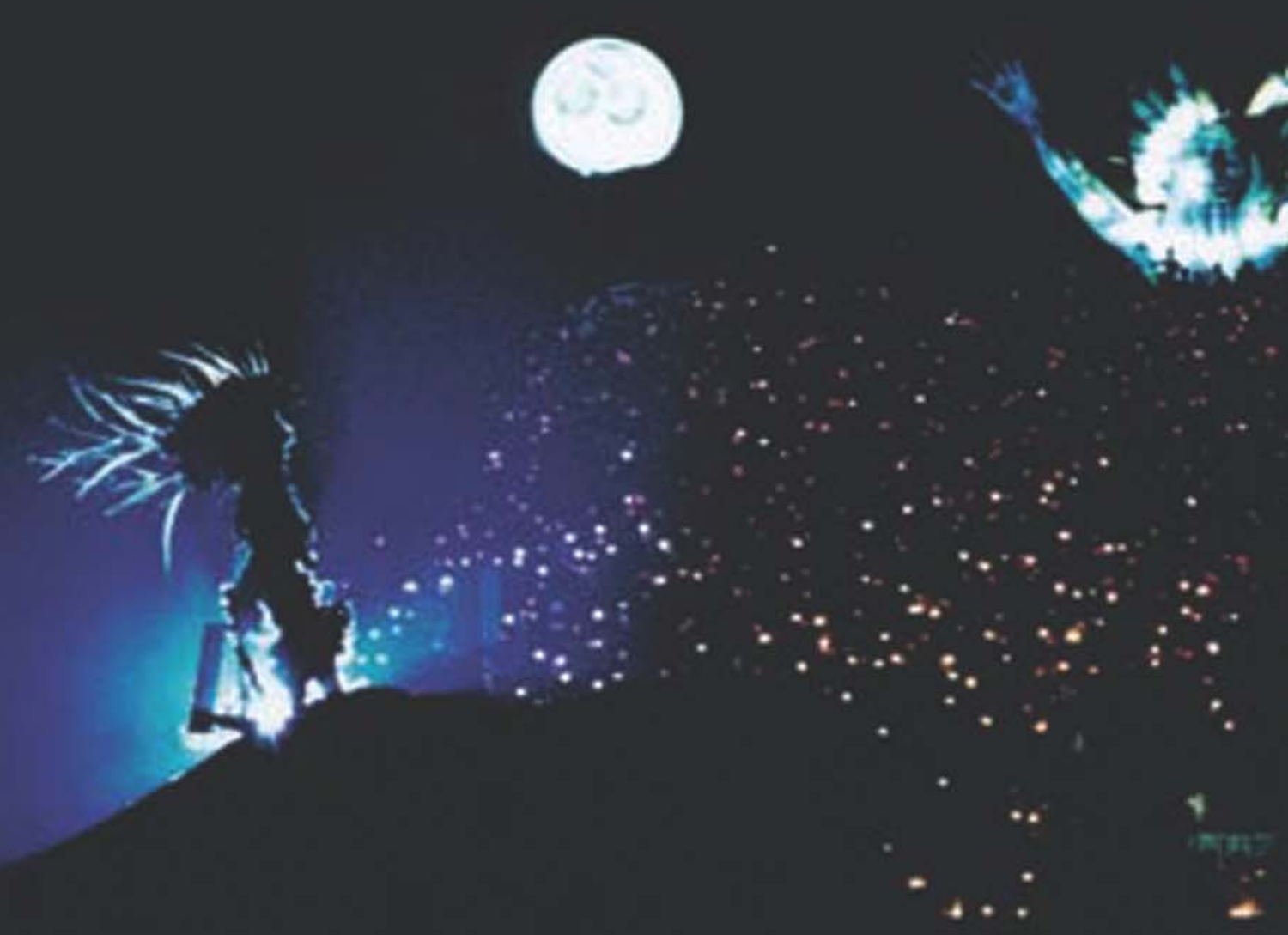

Ritual do Pajé e Tupã 


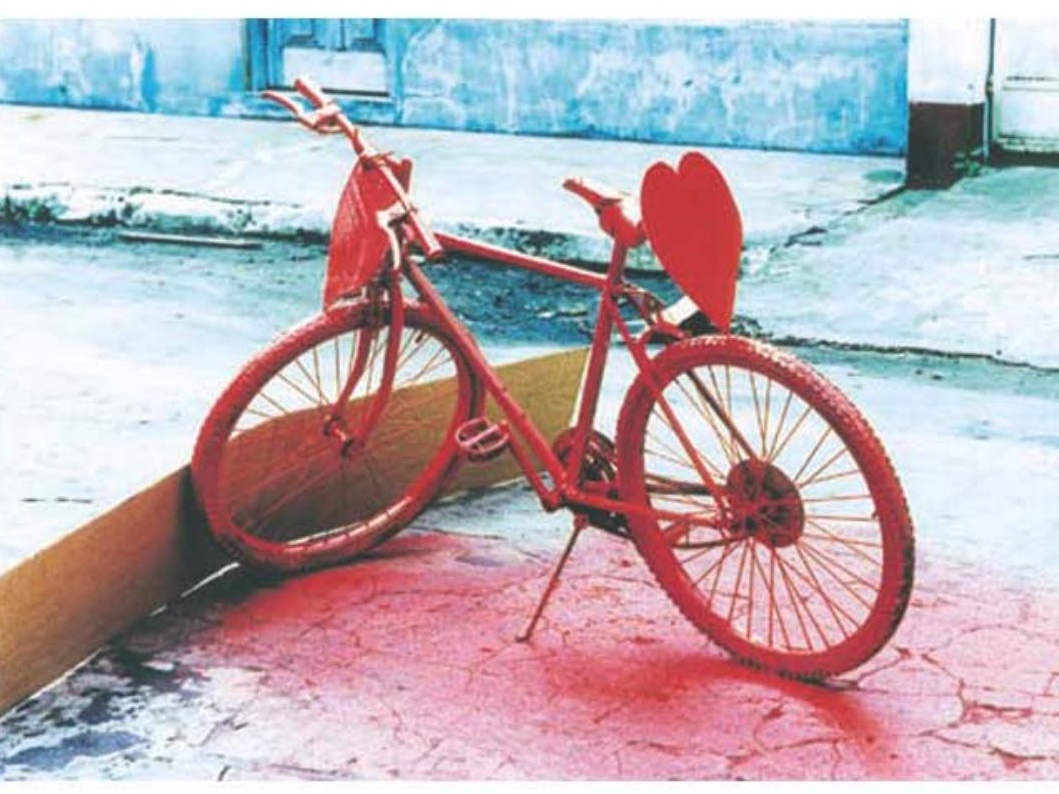

$\therefore * \cdots$

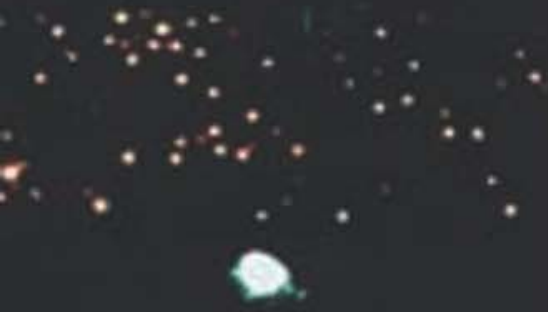

Bicicleta de torcedor do Garantido Pajé Velho

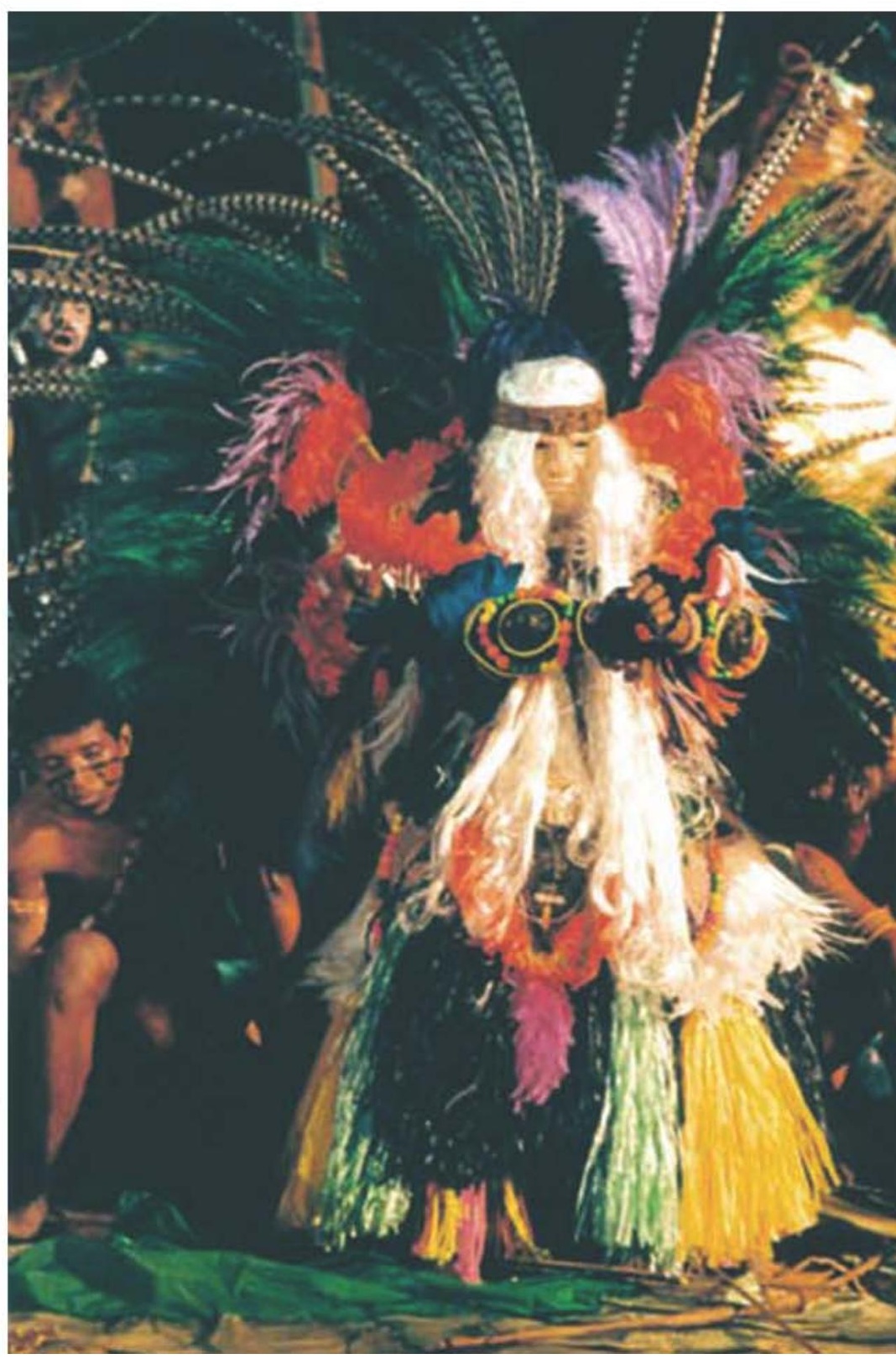



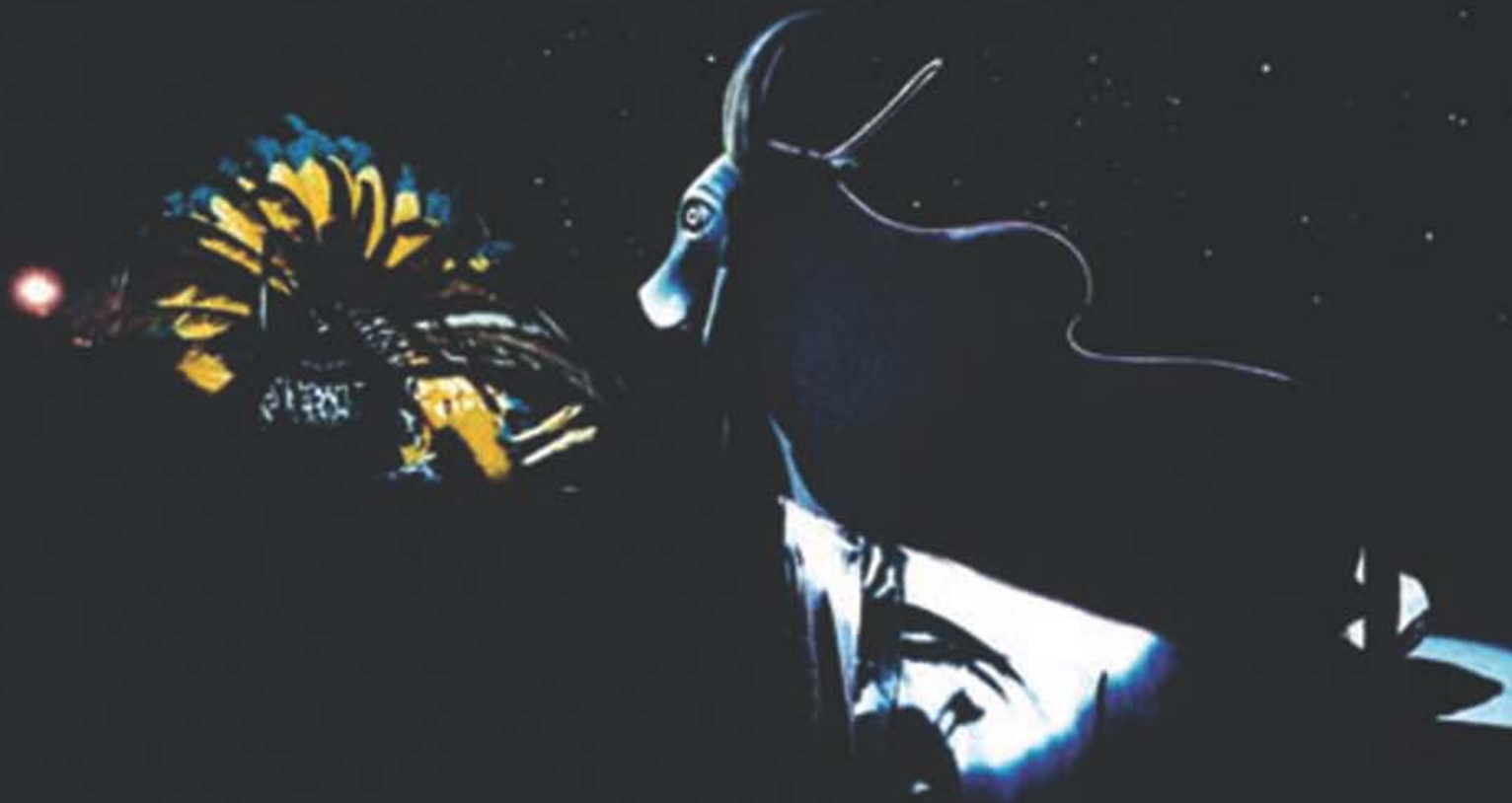

\section{O Caprichoso sobressai na escuridão}

Conjunto do boi: Mãe Catirina, Pai Francisco, levantador de toadas, apresentador, amo do boi

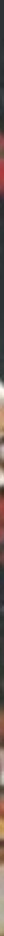

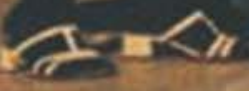




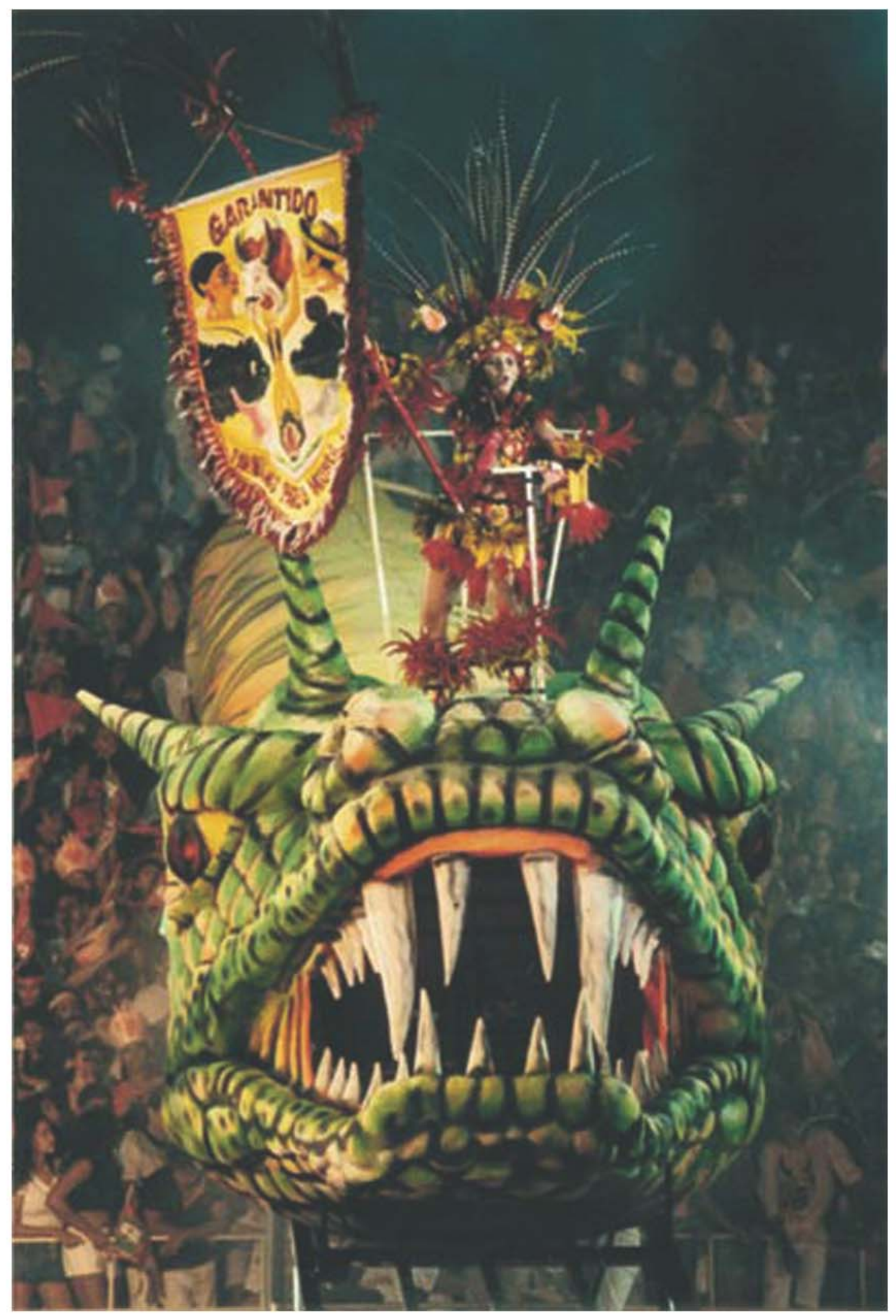

Porta-estandarte do Garantido e cobra-grande 


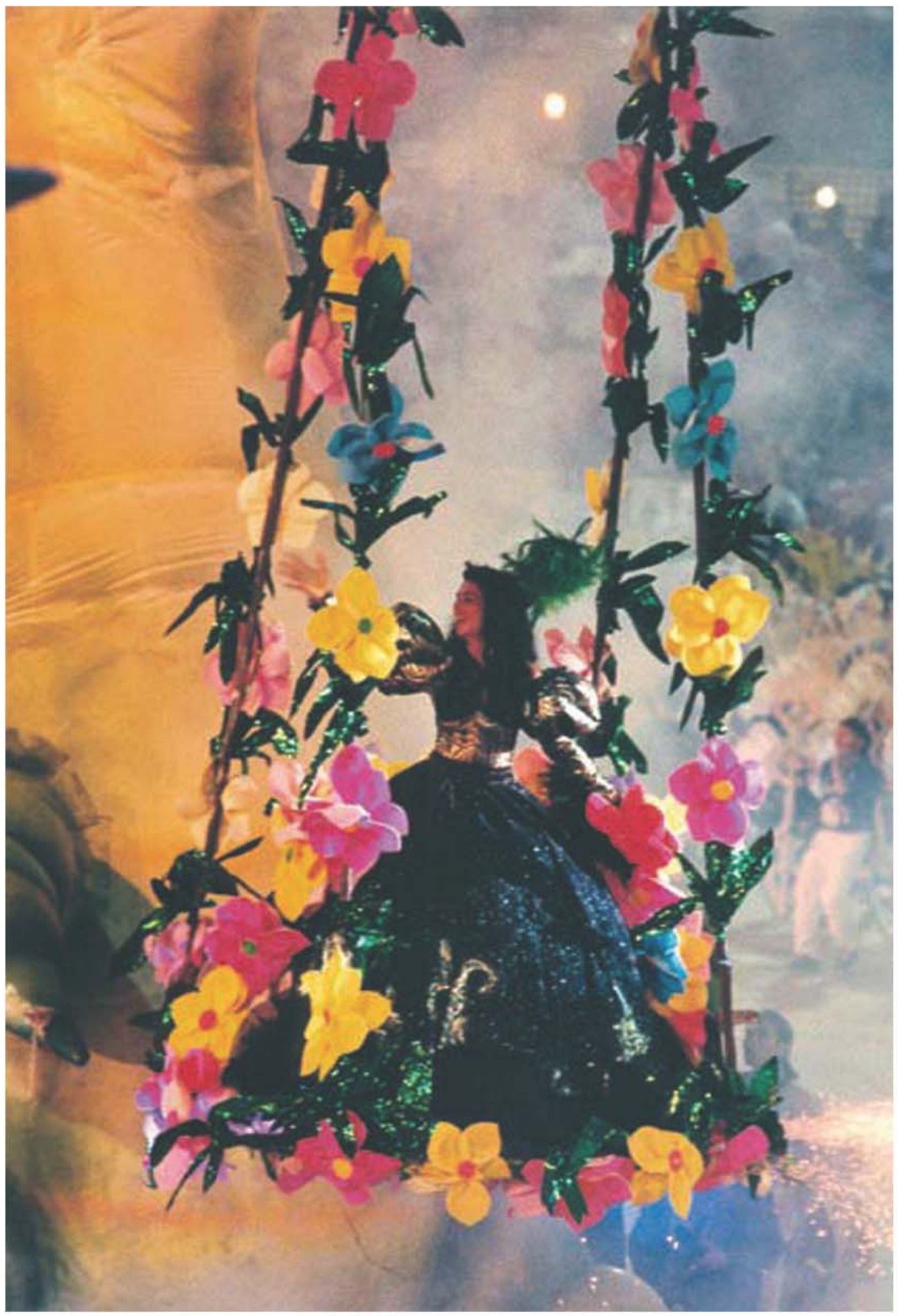

Sinhazinha florida encanta a galera 


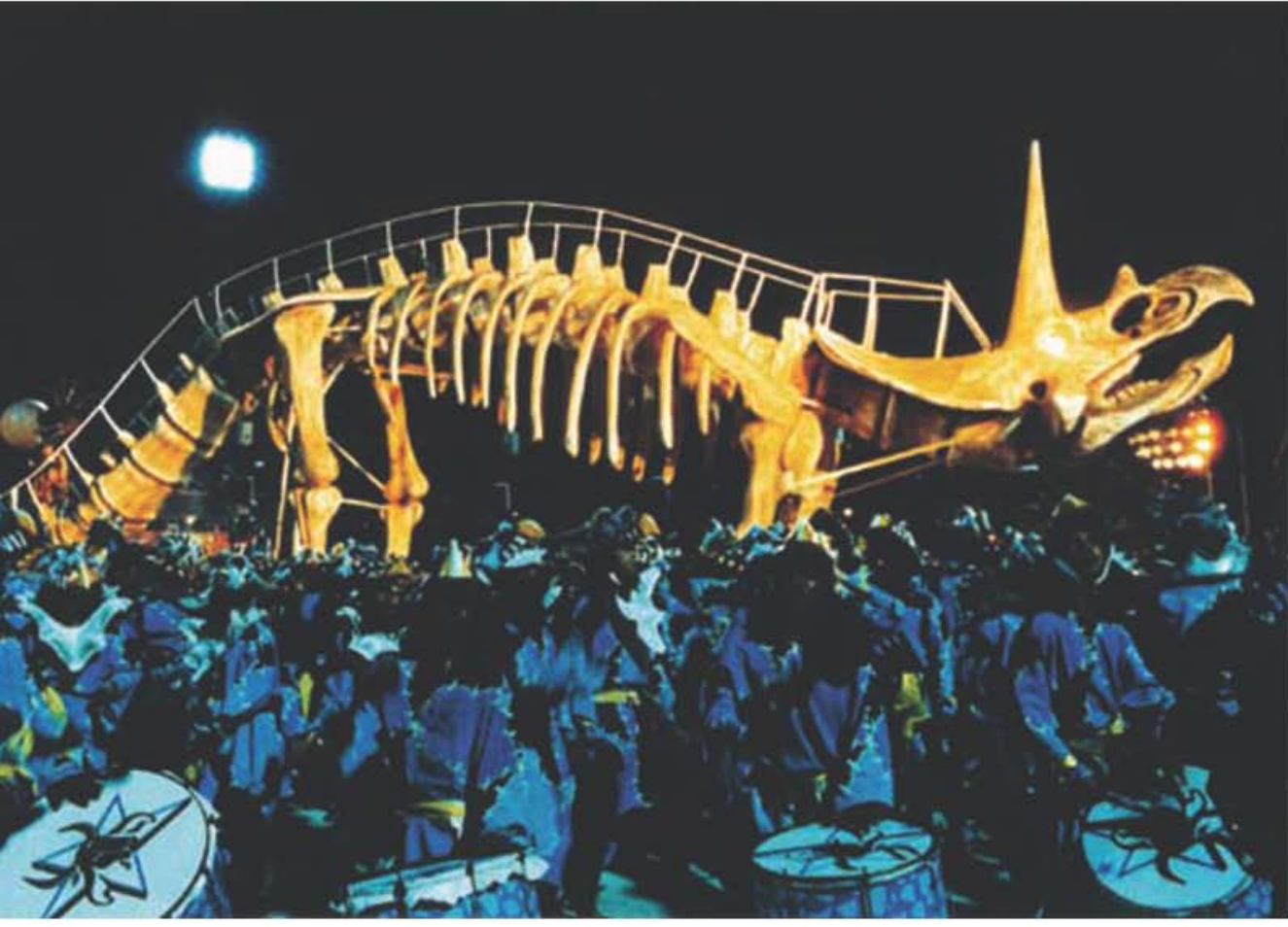

Dinossauro

e marujada de guerra

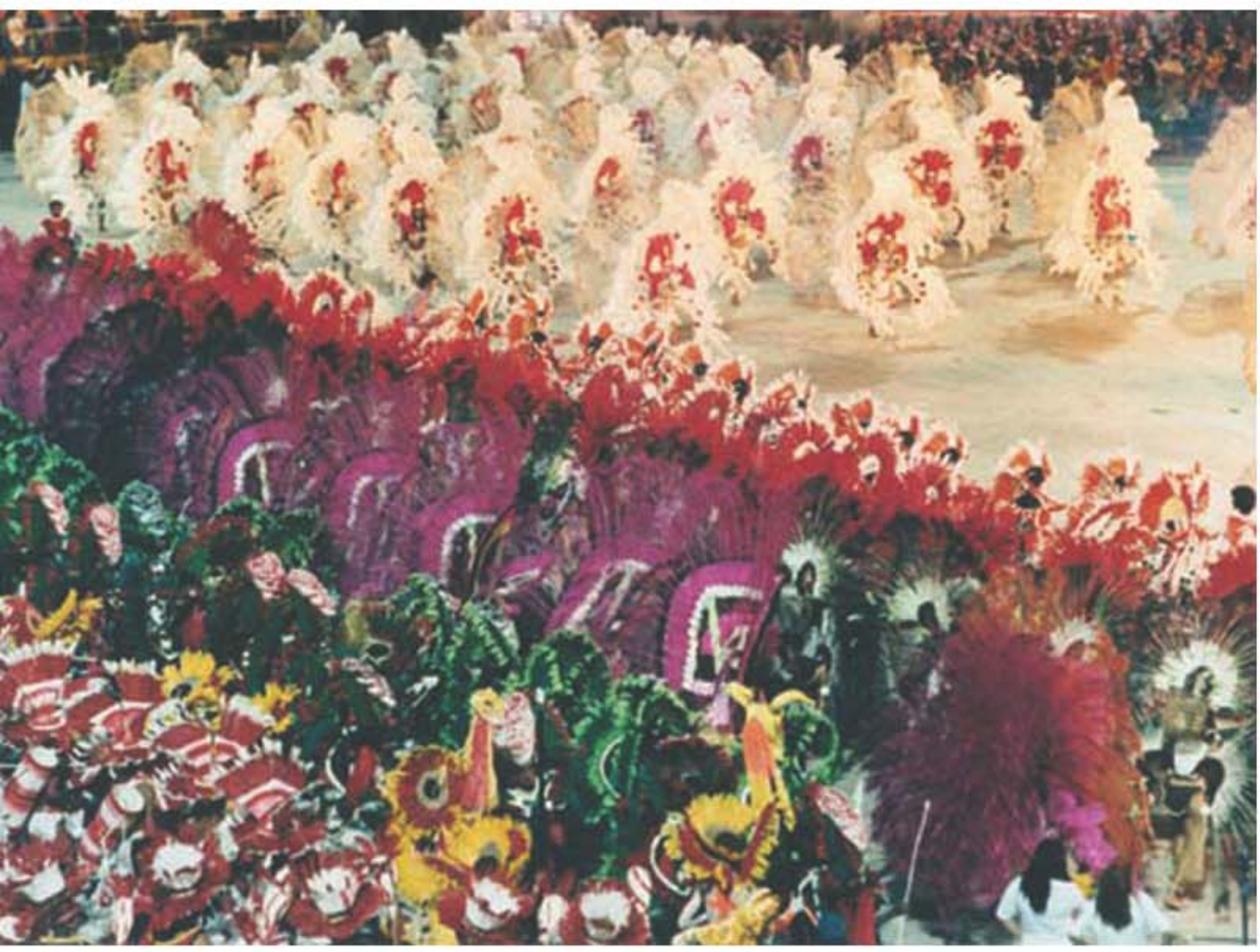

Tribos

apresentam-se no

Bumbódromo 


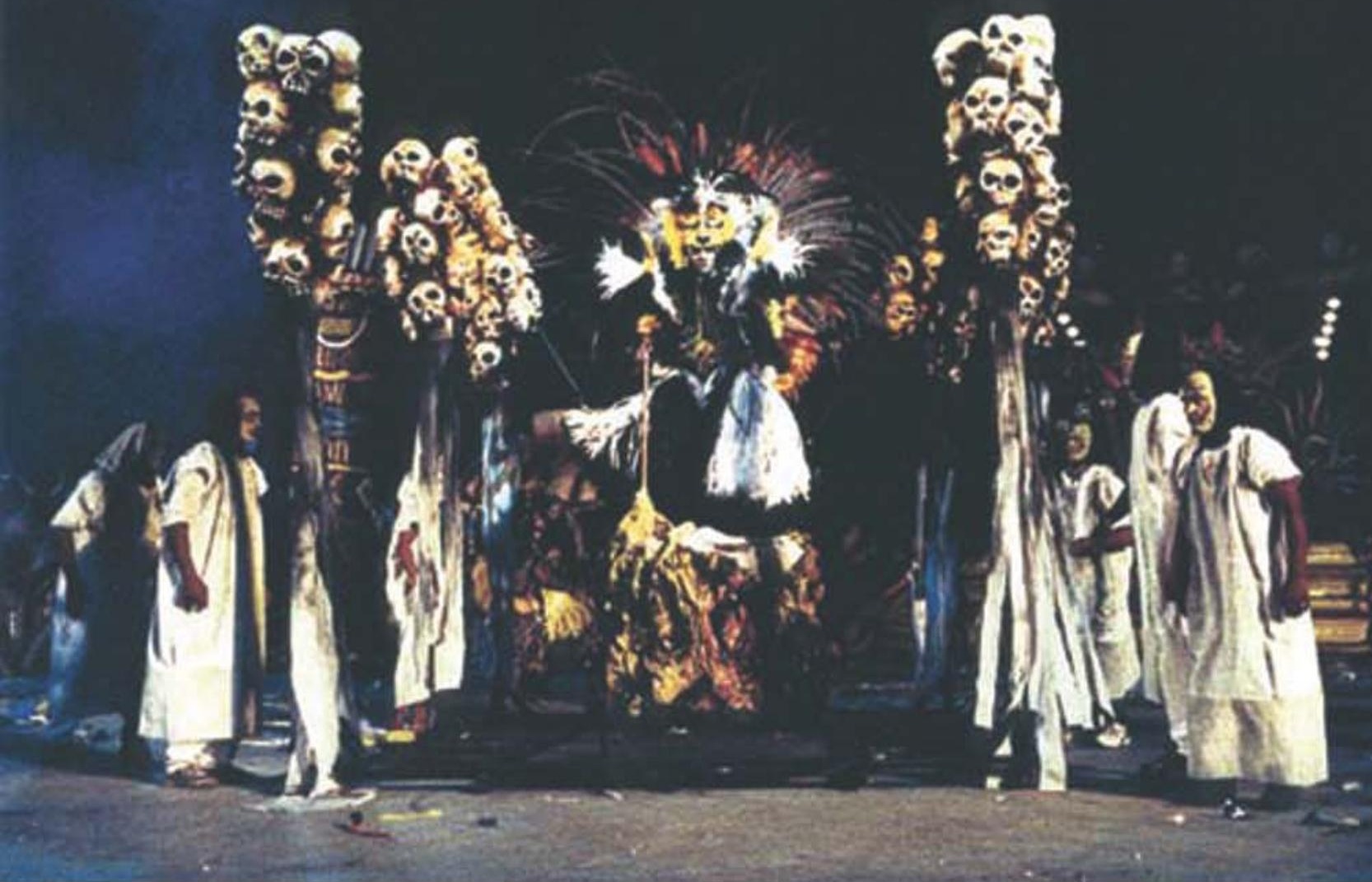

Ritual do Pajé

Rainha do folclore, do Caprichoso

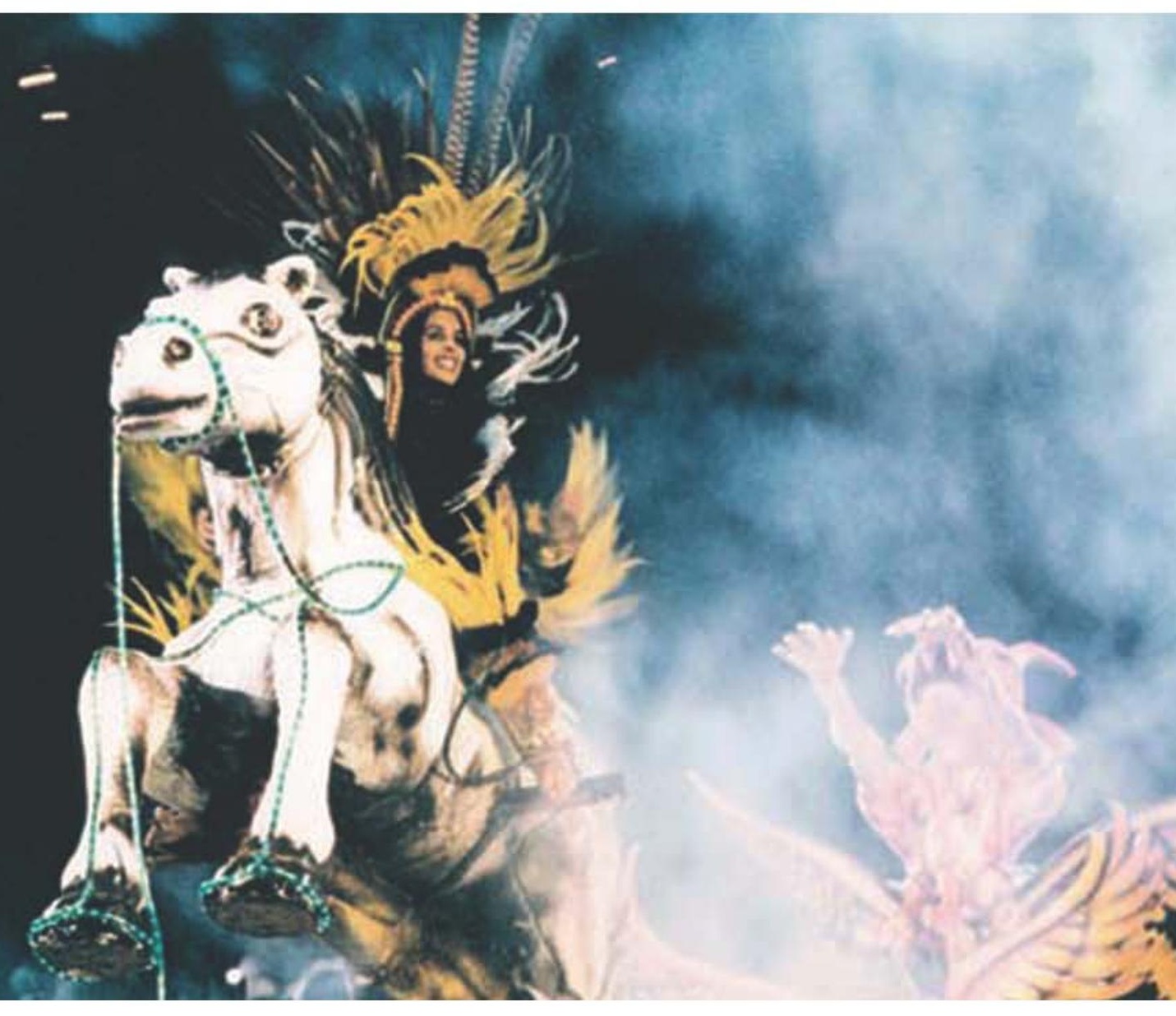




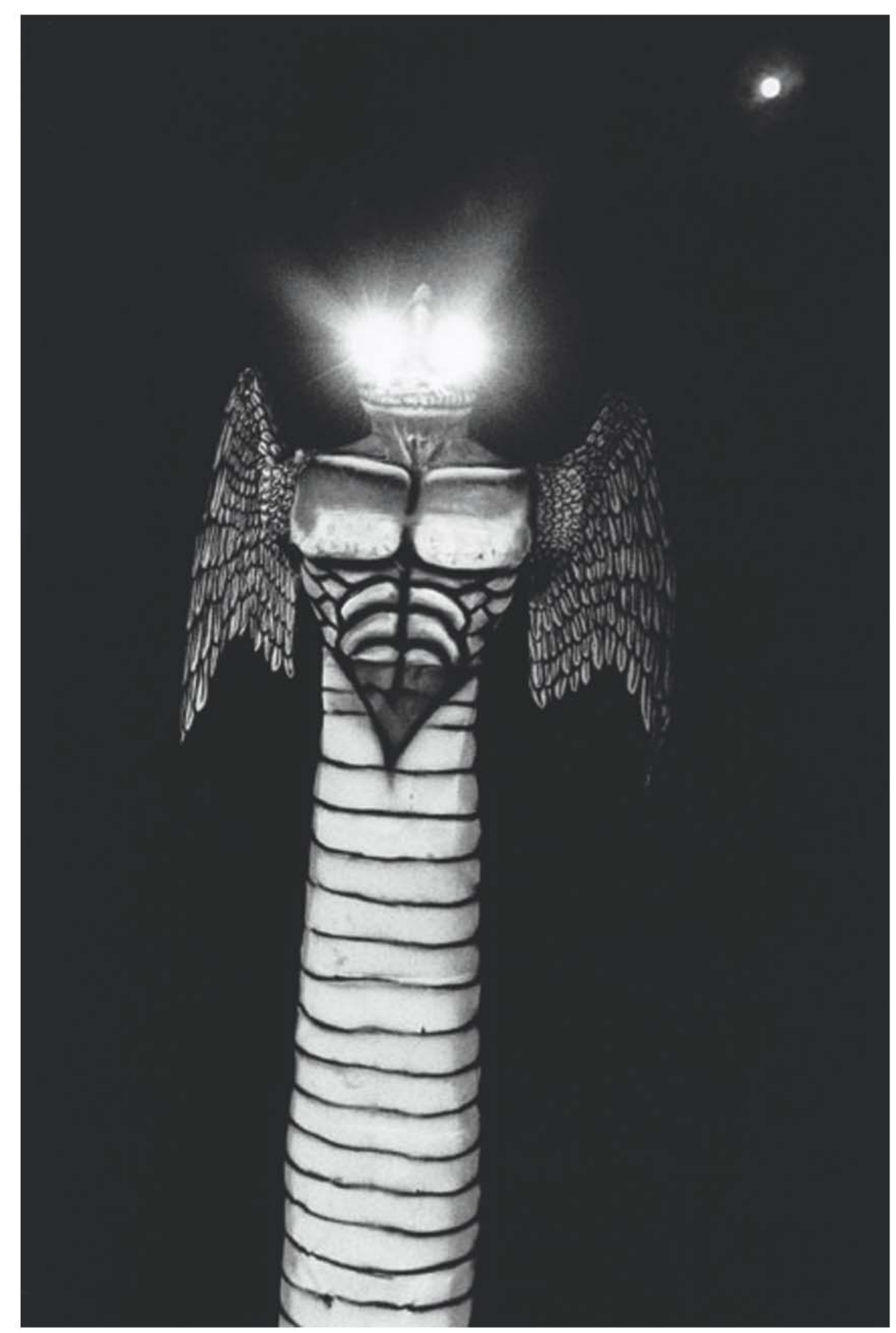

Cobra grande futurista de olhos flamejantes 


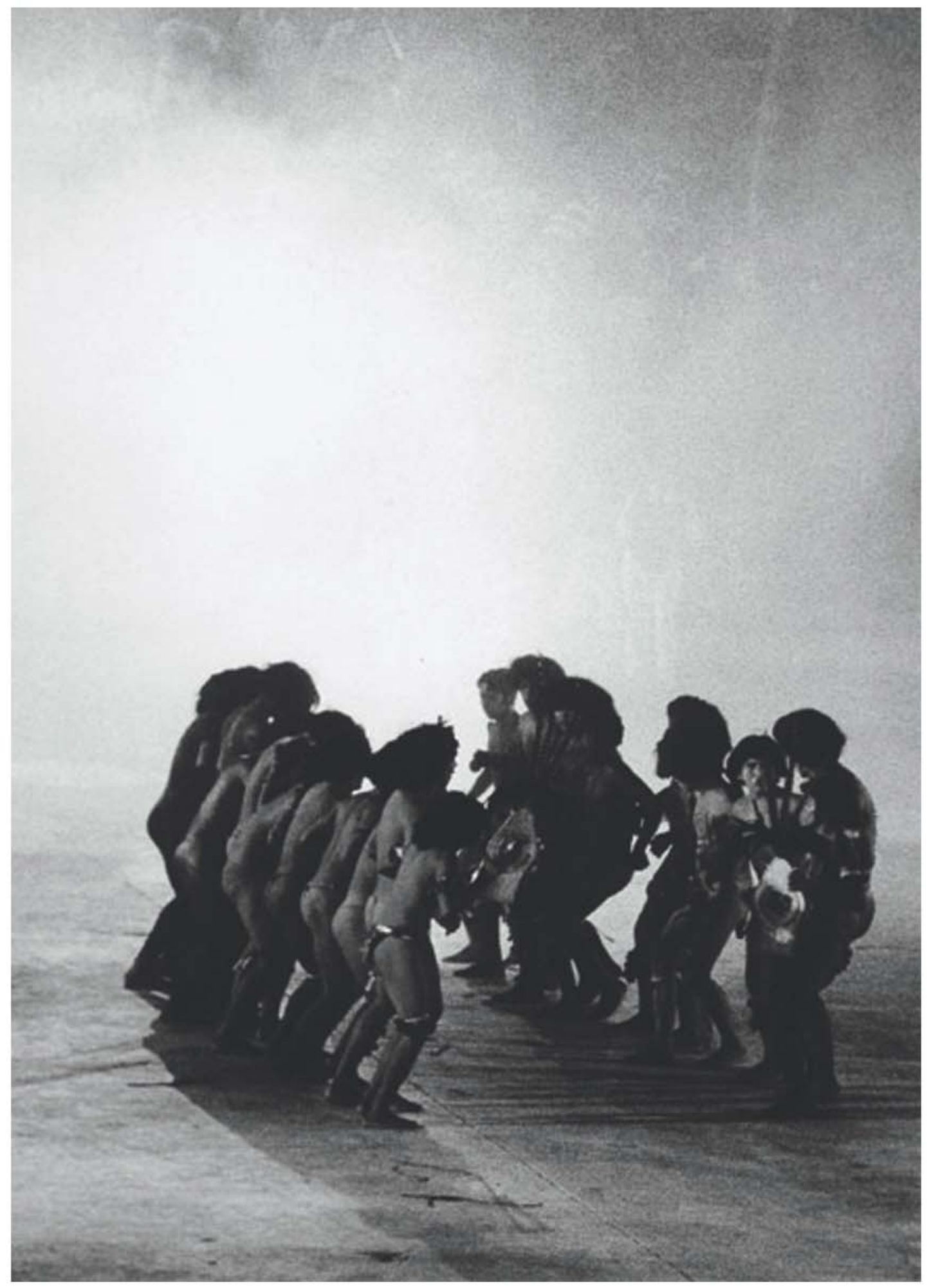

Ritual Weaperiá 